\title{
CORPORATE SOCIAL RESPONSIBILITY AND CORRUPTION RISKS OF ENTERPRISE BOARD MEMBERS
}

\author{
Velga VEVERE \\ Professor \\ EKA University of Applied Sciences, Riga, Latvia \\ E-mail: velga.vevere@gmail.com \\ Inara BRANTE \\ Assistant professor \\ EKA University of Applied Sciences, Riga, Latvia \\ E-mail: inara.brante@inbox.lv
}

\begin{abstract}
Practice of Corporate Social Responsibility applies not only to the labor market and to labor law. Its aim is to encourage society and entrepreneurs to develop a socially responsible entrepreneurship that involves active participation in ensuring of the working and living conditions for both employees and society in overall.In Latvia, there is anactual need to organize and create a socially responsible business environment where the main operating principles are clearly defined and where the main criterion is reputation that plays an important role in ensuring the social stability and sustainability. The company's board implements the company's financial policy and thus bears a responsibility in the face of employees and the third parties involved. The goal of the current study is to research the cases where the legal responsibility of the board members towards third parties occurs and to identify the main corruption risk factors. Two research questions are being proposed: (1) What is the legal background for fighting corruption in enterprise boards in Latvia?; (2) What are the main corruption risks for enterprise board members? The research methods employed in the study are monographic research, comparative analysis of the legal bases and case study. The novelty of the current research lies with the identification of specific risk factors in the field, which will allow working out a set of practical suggestions.
\end{abstract}

Key words: Corporate social responsibility; enterprise board; corruption risks; board member liability; corruption perception index 


\section{Introduction}

Broadly defining the concept of Corporate Social Responsibility (CSR) we can state that it denotates the three-valent relation between employees, businesses and the state, or, in other words - the social partnership. CSR is increasingly recognized as being about having good business practices and its impacts are seen as contributing to an organization's reputation and performance. The latter is becoming more and more important as the value of business becomes more and more reliant on intangible elements. Despite the wide spectrum of approaches to CSR, there is general consensus on its main features: (i) CSR is corporate behavior that exceeds the solely legal requirements, (ii) CSR is a voluntarily adopted socially responsible business practice, (iii) CSR is intrinsically linked to the concept of sustainable development: businesses need to integrate the economic, social and environmental impact in their operations, (iv) CSR is not an optional addition to the core business activities, but rather - the fundamental way, how the things are done taking into account individual and societal interests, as well as concern for environmental issues (Vevere \&Svirina, 2020, pp. 12-13). Practice of Corporate Social Responsibility applies not only to the labor market and to labor law. Its aim is to encourage society and entrepreneurs to develop a socially responsible entrepreneurship that involves active participation in ensuring of the working and living conditions for both employees and society in overall. In Latvia, there is an actual need to organize and create a socially responsible business environment where the main operating principles are clearly defined and where the main criterion is reputation that plays an important role in ensuring the social stability and sustainability. The company's board implements the company's financial policy and thus bears a responsibility in the face of employees and the third parties involved. A good corporate governance practice is grounded in the existing legislation and its provisions; still,the practical implementation within specific contexts and environments play no less significant role.

The goal of the current study is to research the cases where the legal responsibility of the board members towards third parties occurs and to identify the main corruption risk factors. The research methods employed in the study are monographic research, comparative analysis of the legal bases and a case study.In order to reach the goal the authors put forward two research questions: (1) What is the legal background for fighting corruption in enterprise boards in Latvia?; (2) What are the main corruption risks for enterprise board members? The originality of the current research lies in the fact that it identifies specific risks for Latvian enterprises, that makes it possible to work out proposals for risk avoidance. 


\section{Literature Review}

The origin of the term 'corruption' comes from the Latin terms corruptus, or corrumpere which meanspoiled or break into pieces, accordingly. Corruption occurs at all levels of society and at allforms - public, private, locally, nationally and internationally. Internationalization and globalization of business put additional meanings to the concept. Still, an international definition of 'corruption' does not exist, thus, different interpretations of the concept are given by multiple jurisdictions according to their own cultural conceptions.The leading norms that deal with 'corruption' on the international level are the "UN Convention against Corruption(UNCAC)", the Convention on Combating Bribery of Foreign Public Officials (OECD Antibribery Convention) (OECD, 2011; United Nations, 2004).The Council of Europe and the UN Conventions do not define 'corruption', but establish various forms of corrupt offences in order to tackle the problem of corruption. According to these documents, the main forms of corruption are:bribery; extortion; facilitation; payment; collusion; fraud; obstructionof justice; embezzlement, misappropriation or other diversions of property by a public official; trading influence; abuse of function; illicit enrichment; money laundering. OECD explains corruption as "the abuse of a public or private office for personal gain. The active or passive misuse of the powers of Public officials (appointed or elected) for private financial or other benefits" (OECD Glossaries. 2008; Yin, 2018).The Transparency International (TI) defines it as the "misuse of entrusted power for private gain. It hurts everyone who depends on the integrity of people in a position of authority" (Transparency International, 2016).

The UN Global Compact suggests participants to consider the following three elements whenfighting corruption and implementing the 10th principle. The tenth principle against corruption was adopted in 2004 and commits UN Global Compact participants not only to avoid bribery, extortion and other forms of corruption, but also to proactively develop policies and concrete programs to address corruption internally and within their supply chains. Companies are also challenged to work collectively and join civil society, the United Nations and governments to realize a more transparent global economy. There are many reasons why the elimination of corruption has become a priority within the business community. Confidence and trust in business among investors, customers, employees and the public have been eroded by recent waves of business ethics scandals around the globe. Companies are learning the hard way that they can be held responsible for not paying enough attention to the actions of their employees, associated companies, business partners and agents (United Nations Global Compact). At the same time, corruption can be described also by such (more descriptive) terms as 'corporate wrongdoing', 'management fraud' and 'illegal corporate behavior'. When the individual benefits, the organization is typically the victim; when the organization benefits, society is typically the victim; and 
when both benefit, society is typically the victim. Corruption threshold becomes even more important in the contemporary competitive market environment. Corruption in emerging markets is a key social concern as well as a bottom-line issue that affects a corporation's ability to compete. Engaging in anti-corruption strategies is an opportunity for corporations to improve their competitiveness while also limiting resources that are intended for disadvantaged populations from ending up in the pockets of dishonest public officials.

The Transparency International's Corruption Perceptions Index (since 1996) ranks countries in terms of the degree to which corruption is perceived to exist among public officials and politicians.It is a composite index, drawing on corruption-related data from expert and business surveys carried out by a variety of independent and reputable institutions (Vevere \&Zvirgzdina\&Linina, 2017). The lower-ranked countries exhibit untrustworthy and badly functioning public institutions; even though there exist anti-corruption laws, they are often ignored. People frequently face situations of bribery and extortion, misappropriation of public funds and official indifference when seeking justice. Higher-ranked countries tend to have higher degrees of press freedom, access to information about public expenditure, stronger standards of integrity for public officials, and independent judicial system. The higher score, the lower corruption level (Rohwer. 2009).The index, which in 2018 ranks 180 countries and territories by their perceived levels of public sector corruption according to experts and businesspeople, uses a scale of 0 to 100 , where 0 is highly corrupt and 100 is very clean. More than two-thirds of countries score below 50 on this year's CPI, with an average score of just 43. It reveals that the continued failure of most countries to significantly control corruption is contributing to a crisis in democracy around the world. While there are exceptions, the data shows that despite some progress, most countries are failing to make serious inroads against corruption (Transparency International. Corruption Perception Index 2018).William P. Olsen in "The Anti-Corruption Handbook. How to Protect Your Business inthe Global Marketplace" (Olsen, 2010) analyzes possible threats corruption pose upon business organizations and society in general operational costs, legal risks, and competitive risks, as well as reduced government services for the disadvantaged, constraints on foreign direct investment in high-corruption countries, and crime and instability resulting from decreased trust in government.Corporations can play a leadership role in the anti-corruption effort by treating corruption as a strategic Corporate Social Responsibility (CSR) issue and seeking proactive solutions to social problems critical to the business. More specifically, corporations can ensure compliance throughout all their divisions and countries; shift from diffuse declarations to outcome-oriented pacts that create effective incentives for behavior change; expand efforts to influence public sector corruption; leverage their financial, technical, and communication assets; and align and integrate resources and staff in order to execute swiftly on these approaches. The important principles 
of the strategic CSR, in Olsen's opinion, are related to (1) support of upper management; (2) a comprehensive and clearly articulated code of conduct, as well asclear policies and procedures relative to seeking guidance and makingdisclosures; (3) compliance monitoring by ethics officers and/or company board; (4) training and communication (regular ethics and compliance training programs should be held for all company employees, including board members and senior management officials); (5) due diligence (conducting prompt and thorough due diligence reviews is vital for ensuring that a compliance program is efficient and effective); (6) auditing and internal controls (auditing and monitoring of systems of internal accounting controls contribute to building an effective compliance program by the early detection of inaccuracies and misconduct); (7) reporting mechanism (creating reporting mechanisms with adequate policies on confidentiality and nonretaliation, as well as other safeguards related to reporting, is extremely important); appropriate response (in instances of noncompliance, a company should take the necessary preventive steps to ensure that the questionable conduct does not recur in the future). The expectation with all these instruments is that business organizations will act in a socially responsible manner towards corruption by putting in place measures ranging from adopting codes of conduct to promoting employee awareness and compliance with policies of the business organization. These instruments therefore create an expectation that businesses will integrate anti-corruption measures within their corporate social responsibility (CSR) agenda (Carr\&Outhwaite, 2011).In fighting corruption CSR has certain advantages and disadvantages. Among advantages we can mention here: appearance the organization as the responsible one; the harmonization of rules readily and speedily in the face of diverse legal systems and delays in the adoption and implementation of conventions; selfimposed regulatory framework. At the same time CSR can be perceived as solely public relations activity without deeper meaning; the "free-rider" problem, since many may take little or no action, hoping to avoid the cost of such action whilst absorbing some of the benefits of the action of others, for instance improved public perceptions of the industry as whole (Arafa, 2011).

What is a board of directors to do, in the face of competing demands on the resources of the company and conflicting perspectives on what their roles are and should be? Someone is the board of directors. Boards are, in general, responsible for business performance, financial results and operating strategy. They can be held accountable for mistakes of corporation in the face of law or public opinion. Boards play four interlocking roles: they (1) set direction, (2) marshal the resources needed, (3) monitor and report on the resulting actions, and then (4) evaluate the result so as to enhance future performance by adjusting the direction. These roles serve two main purposes that need to find a balance but can frequently come into conflict: controlling the performance of managers and contributing to the creation of value. If the emphasis of corporate governance falls too heavily on the side of value creation, managers and directors may ignore the growing risks. If it falls too heavily on 
monitoring and control, then innovation and creativity may suffer, and so too the potential for growth (Nordberg, 2011) The boards signal what is and what is not acceptable. Boards face competing and conflicts demands, on the resources of the company and on their own attention and motivation. Board members should act independently in the interest of the company and should not act as representatives of different constituencies or take part in regulatory decisions concerning the SOE. All potential conflicts should be disclosed and managerial decisions should be taken without hesitation.

In order to identify the risks of corruption an international survey of 347 State Owned Enterprises (SOE) from 213 companies in 34 countries was carried out. Results of the survey outline where corruption and other irregular practices in SOEs have occurred in recent years. It explores how a SOE and respondent characteristic, such as the company's sector or the respondent's position, influences the perception of corruption-related risks. Data was deconstructed to understand more about the specific high-risk areas of public procurement, conflict of interest, influence in decision-making and bribery (OECD, 2018).42\% of 347 SOE respondents reported that corrupt acts or other irregular practices transpired in their company during the last three years. Corruption and other irregular practices reportedly involved all hierarchical levels of the SOE. Those most commonly implicated were nonmanagement employees and mid-level management. Their transgressions occurred more in the day to day operations of the company and were thus primarily the responsibility of the Board. One in five respondents saw board members involved in such corruption and other irregular practices, emphasizing the responsibility of the state-ownership entity to promote and contribute to sound boards. Board members and those in charge of integrity functions (audit, compliance or legal counsel) reported seeing corrupt activities and irregular practices more than executive management. The top three risks of corruption and irregular practices considered the most impactful, according to the survey, were: (1) receiving bribes; (2) falsification and/or misrepresentation of company documents; (3) false accounting and fraud. Another research to be mentioned here is the one launched by the Transparency International in 2016(Transparency International, 2016). The main conclusions of the report were the following:

- Emerging market multinationals continue to fall short of the corporate transparency standards that are expected of multinationals operating internationally;

- Publicly listed companies perform better in all dimensions than stateowned enterprises and privately held companies;

- Country-by-country reporting remains the weakest result for a majority of emerging market multinationals;

- The performance of Chinese companies continues to be disappointing overall, but there are a few notable exceptions, particularly with regard to the disclosure of anti-corruption programs; 
- Chinese entities have different standards of disclosure: levels of transparency for China-based state-owned parent companies are lower than those adopted for their publicly-listed foreign subsidiaries and associated entities.

Taking into account these results the main recommendations were the following: implementation of anti-bribery laws and provision of necessary sources to enforce them; adoption of rules for mandatory company reporting on anti-corruption measures; requirement to companies to disclose their corporate structures; requirement to all companies to publish financial accounts on acountry-by-country basis.

The goal of the current study is to research the cases where the legal responsibility of the board members towards third parties occurs and to identify the main corruption risk factors.

\section{Methods}

The research methods employed in the current article are a comparative analysis of the legal bases and other regulative documents, and case studies. The legal documents analyzed were: (1) "Commercial Law of the Republic of Latvia", article 169The Liabilities of the Members of the Board of Directors and Council (Legal Acts of the Republic of Latvia, 2000a); (2) "Good Practice Guidance on Internal Controls, Ethics, and Compliance" by OECD (OECD Glossaries, 2008);(3) CSR Platform in Latvia (CSR Platform in Latvia, 2011).

The second method applied in the current research is the case study. Case study research through reports of past studies, allows the exploration and understanding of complex issues. It can be considered a robust research method particularly when a holistic, in-depth investigation is required. Through case study methods, a researcher is able to go beyond the quantitative statistical results and understand the behavioral conditions through the actor's perspective. There are several categories of case study. R. K. Yin [21] notes three categories, namely exploratory, descriptive and explanatory case studies. First, exploratory case studies set to explore any phenomenon in the data which serves as a point of interest to the researcher. Second, descriptive case studies set to describe the natural phenomena which occur within the data in question, for instance, what different strategies are used by a reader and how the reader use them. The goal set by the researcher is to describe the data as they occur. Third, explanatory case studies examine the data closely both at a surface and deep level inorder to explain the phenomena in the data. The current research makes use of the third type of the third type case study, i.e., the explanatory one. The authors analyze legal background, commentaries and verdicts of several court cases related to the liability of company board members, paying a special attention to the risks of corruption.The court cases (No. SKC-102/2014 and SKC-102/2014) were 
selected for analysis because they both concerned company board member liabilities.

\section{Comparative Analysis of Legal Bases}

The choice of the documents to be analyzed within the current investigation ("Commercial Law of the Republic of Latvia", "Good Practice Guidance on Internal Controls, Ethics, and Compliance" by OECD, CSR Platform in Latvia, respectively) was determined by the fact, that they directly deal with the matter of corruption of company board members. For this reason the research field was even more narrowed down till the particular sections of the law.

The Commercial Law of the Republic of Latvia, section 169 enumerates the liabilities of the members of the board of directors and council (Legal Acts of the Republic of Latvia, 2000a).The liabilities are the following:

1. Members of the board of directors and council shall perform their duties as would an prudent and careful owner;

2. Members of the board of directors and council shall be solitarily liable for losses that they have caused to the company;

3. Members of the board of directors and council shall not be liable in accordance with Paragraph two of this Section if they prove that they have acted, as would an prudent and careful owner;

4. A member of the board of directors and council shall not be liable for losses caused to the company if he or she has acted in good faith within the framework of a lawful decision of the meeting of shareholders. The fact that the council has approved the actions of the board of directors shall not release the members of the board of directors from liability to the company.

In accordance with the provisions of the Commercial Law, the Board is considered to be one of the governing bodies of the Corporation and its executive body, which manages and represents the corporation. Considering that the election of a member of the Board is a vote of confidence, the position of a member of the Board is also considered a position of trust. As a trustee, a member of the board of directors, on the one hand, has been given a special mandate to handle the property of the corporation and maximize the profits of the capital company, but on the other hand, is obliged to take care of the preservation of the property. The Law provides that situations to be evaluated in relation to corruption risks are: the supervision and/or control of the performance of private individuals' activities, the functions of the institution, including in the field of commercial activities, and the right to dispose of the funds and property of the public.

Since 30 May, 2014 Latvia is a member of the "Convention on Combating Bribery of Foreign Public Officials in International Business Transactions" entitled "Good Practice Guidance on Internal Controls, Ethics, 
and Compliance" (OECD Glossaries, 2008). This document is addressed to companies for establishing and ensuring the effectiveness of internal controls, ethics, and compliance programs or measures for preventing and detecting the bribery of foreign public officials in their international business transactions, and to business organizations and professional associations, which play an essential role in assisting companies in these efforts. It recognizes that to be effective, such programs or measures should be interconnected with a company's overall compliance framework. Business organizations and professional associations may play an essential role in assisting companies, in particular SMEs, in the development of effective internal control, ethics, and compliance programs or measures for the purpose of preventing and detecting foreign bribery. Such support may include:

- dissemination of information on foreign bribery issues, including regarding relevant developments in international and regional forums, and access to relevant databases;

- making training, prevention, due diligence, and other compliance tools available;

- general advice on carrying out due diligence;

- general advice and support on resisting extortion and solicitation.

In 2011, the Latvian Employers' Confederation established a CSR platform. In relation to corruption, the Memorandum it is stated Reducing and eliminating corruption risks by developing common standards for business ethics at sectoral level and putting them into practice (CSR Platform in Latvia, 2011).

In the Platform the CSR principles to be followed by board members are related to:

- the environment (preventive measures to prevent global warming, prevention of pollution, respect for the interests of future generations),

- fairness in the employment of workers (principles of openness and ethics, free competition, fight against corruption, etc.),

- public participation / development (involvement, impact),

- consumer interests (social security),

- management of the organization (efficiency, compliance with laws, responsibility),

- work (occupational safety and health,

- development of human resources, respectable conditions),

- human rights (civil rights, economic and social rights, labor rights),

- identification and evaluation of corruption risks in day-to-day company operations.

Therefore, companies should develop internal corporate governance principles that define clear and unambiguous responsibilities, powers and responsibilities of the board, thus ensuring the success of the board and the 
increase in public value. The Board approved by the company should be capable of providing a sufficiently critical and independent attitude in assessing and making decisions.

From the analysis of the legal and other regulative documents we can come to certain conclusions regarding elimination of corruption risks by the members of company board of directors. A corporation (Limited Liability Company and joint stock Company) is a legal person under the Commercial Law, which is liable for its liabilities only with its property. Members of the company are not liable for the company's obligations and the company is not responsible for the obligations of the participants. The board of the company is the executive body of the company that manages company and creates public trust. The board also has no obligation to answer the public's obligations, but this does not mean that the board members of the company are not limited to their own actions, are not responsible for their actions, or can "violate" the law by hiding behind the company. Claims against the members of the board may be brought in two cases - if a member of the board violates the provisions of the law or if a member of the board acts in bad faith and contrary to the interests of the society (does not act as a good and diligent owner). In addition, an action may be brought against any act of a member of the board that violates the law or any misconduct, but only that has caused the public to suffer. An action may be brought against a member of the board for violations of the law if such action has resulted in loss to the public. The Supreme Court has indicated that in a law-governed state, a situation where a natural person deliberately acts unlawfully, without assuming liability for damages caused to third parties, cannot be accepted. The company has a duty to comply with the law when conducting any activity and it is the duty of the board members who are responsible for managing the company to ensure that the company does not violate the law. Society must comply with the Law on Accounting, Labor Law, Tax Law, Commercial Law, etc.

\section{Law Implementations and Court Cases}

There are periodic discussions in the public sphere as to whether the responsibilities of board members are proportionate in Latvia. Opinions range from "board members not responsible for anything" to "board members' liability is so disproportionately high that we will soon have no one willing to take the risk of serving on the board. The Commercial Law laconically requires board members to act as diligent and diligent landlords; otherwise they will have to bear the losses, if any, as a result of the board's actions. The issue at stake is whether board members also have to answer before the company's creditors, i.e. on outstanding commitments. Latvian law provides for two exceptions to the general principle that the board is not liable for the liabilities of the company. The first case is provided for in the Insolvency Law (Legal Acts of The Republic of Latvia, 2000b). Members of the board shall be liable for any outstanding liabilities of the insolvent company if, at the 
commencement of the company's insolvency proceedings, accounting records are not made available to the insolvency administrator or if they are in a state of inability to obtain information about their business transactions. It is a matter of course that the management of the company is responsible for organizing the accounting of the company. Unless something extraordinary has happened, non-disclosure of documents usually indicates that the members of the board have something to hide for the period prior to insolvency.The second case in which members of the board of directors of a company are liable for the liabilities of the company is provided for in the Taxes and Duties Act (Legal Acts of The Republic of Latvia, 1995).It is possible for a member of the board to recover a company's tax arrears if several prerequisites coincide. The most significant of these are: a) debt exceeding 50 minimum monthly salaries, b) debt incurred during the life of the board member, c) after tax debt the company has disposed of assets to members of the board, d) indebtedness, e) board members filed for company insolvency. Board members of the company may at any time avoid liability by filing for company insolvency. Again, this framework is not unique on an international background. The Board's liability for tax liability is, for example, governed by Swedish and Canadian law. Moreover, it is much tougher in these countries. The Ministry of Finance and the State Revenue Service emphasize that the study of foreign experience leads to the conclusion that in cases where a company has overdue tax payments, the tax administration has a broader legal framework regarding the rights and obligations of the tax administration to recover these overdue taxes. In certain cases, the tax debt of a company is "transferred" to the officials in charge of that company. In the United Kingdom, until 2009 the directors' liability was limited to value added tax, whereas from the 2009 audit surcharges, personal liability of members of the board may be extended to value added tax and other taxes. In Estonia, in relation to the audit surcharge, "board members are jointly and severally liable in cases of fraud or gross negligence where the debt cannot be recovered from the tax debtor". The Swedish Tax Code contains rules on the liability of former company officials for late payment of taxes in cases where the tax administration proves that the official acted intentionally or with gross negligence, with the typical example of not filing an insolvency petition (Zakenfelde, 2015).Thus, it can be concluded from the stated above that neither in the level of legislation nor in the case law there is reason to talk that in Latvia the responsibility of the Board is disproportionately high and the members of the Board take more risks than in other countries with similar economies. Although the court practice does not yet provide a much elaborate, legally formulated explanation of what it means to be a good and diligent entrepreneur in running a business, any board member will be able to find answers, not only consulting with lawyers but listening to his or her own voice and conscience.

It should be taken into account that risk is an integral part of commercial activity, since no-one in the business can guarantee that contracts 
will be executed, payments made, etc. Therefore, reasonable business risk is normal and tolerable. There will always be a question of how to distinguish reasonable risk from the unreasonable one. Business judgement rule provides a formula for reasonable risk in transactions: Good faith + loyalty + decent behavior.

In its turn, in the Judgment of the Department of Civil Cases of the Supreme Court of the Republic of Latvia of May 27, 2014, case no. SKC102/2014 (Republic of Latvia Supreme Court. Senate). The Supreme Court set out the interpretation and application of the concept of "prudent and careful owner", stating that the evaluation of this circumstance is very important as condition for the discharge of the board members. Such terms used in Article 169 of the Commercial Law are open (uncertain legal) concepts or general clauses, the content of which is left to the discretion of the enforcer. The openness of the rule allows to seek the fairest solution to an individual case. Applying these concepts, the court's task is to fill them with legally meaningful content, reflecting in the judgment the reasoning behind its conclusions, i.e. the court must justify what sources of law (non-statutory sources, such as moral, social values, natural order, etc.) have been taken into account when specifying the content of the term contained in the provision and it must be disclosed how it has affected the legal classification of the circumstances of the dispute. In its judgment, the court states that in order to determine whether a board member is liable, the following preconditions must be established: (1) the existence of damage to society; (2) the conduct (action or omission) of the official; (3) there is a causal link between the conduct of the official and the loss. A member of the board can only discharge himself or herself from liability by proving that he or she acted as a diligent and diligent landlord, that is to say, has not committed any slight negligence (see Article 169 (3) of the Commercial Law). Thus, a member of the board must act with the utmost care, since Article 169 of the Commercial Law does not require the public to prove the fault of a member of the board, but on the contrary presupposes the presumption of guilt of that official. In other words, the third paragraph of Article 169 of the Commercial Law, by way of derogation from the general principle of civil procedure regarding the burden of proof, places the burden of proof (guilty or not guilty) on the board (council) member. Conversely, in a situation where a board member is unable to prove this, his fault is presumed. The doctrine of law, revealing the meaning of the provisions of Section 169 of the Commercial Law, states that the Department of Civil Cases of the Supreme Court has no reason to doubt that conduct of a board member is contrary to reasonable commercial practice and that the actions and losses of the official, the fact that the member of the board is not maliciously infringed is of no legal significance as he is liable for everyone, including slight negligence. Consequently, it can be concluded that the liability does not arise only if the member of the board proves that he has acted as a prudent and careful owner in the given situation, that is, he has not tolerated even slight negligence. 
According to Article 1646 of the Civil Law (Legal Acts of The Republic of Latvia, 1992) theordinary negligence shall be considered to be that lack of care and due diligence as must be observed by any reasonably prudent and careful owner.The article 2295 of the Civil Law, in turn, stipulates that the trustee must act with the utmost care in performing the task assigned to him, and he is liable to the trustee for any negligence. It follows from the Commercial Law that the term "due diligence obligation" includes:

- obligation to comply with the law;

- loyalty to society

- compliance with the statutes;

- respect and enforcement of the decisions of the meeting of the participants

- concern for public affairs / proper (responsible) management of the company

- Loyalty to society is primary

- loyalty to members' interests is not a direct responsibility of the board member

- in the event of a collision obligation with the private interests of the board member, the first priority shall be the resignation option.

- obligation to provide settlement (explanation) to the public.

While evaluating the existing case law, the most typical violations of the duties of board members are:

- Wasting (unnecessary transactions: transactions above or below normal value (gaining property), unpaid transactions without members' knowledge);

- Obtaining personal benefits at the expense of the community;

- Unauthorized Competition;

- Ignoring available information (e.g. non-verification of counterparty insolvency);

- Non-elimination of losses, though possible;

- Failure to file an insolvency application to halt the build-up of liabilities however, the more severe consequences should be considered).

In its judgment of 27 May 2014 in case no. SKC-102/2014 in the analysis of the circumstances of the case, the Supreme Court states:

- Firstly, that the damage caused to Bulduru Nams, Ltd. was caused by the defendant's unlawful omission in the form of blocking of the real estate purchase agreement, notwithstanding the adverse consequences of Section 1730 of the Civil Law (as well as the cash agreement);

- Secondly, board members are relieved of their liability to the public only if they can prove that they have acted as diligent and diligent landlords, which means that they have not been negligent;

- Third, the board member is required to make all necessary information and assess the public's potential risks to make an adequate decision, but the defendant, as the court has found, has failed to provide evidence that the real estate transfer agreement is not in the public interest (Republic of Latvia Supreme Court. Senate). 
The judgments of the court is therefore justified in concluding that, in the absence of proof of action in the applicant's interest, the member of the board is liable for the damage caused to the company and must be fully compensated.

It can be concluded that neither in the level of legislation nor in the case law there is reason to talk that in Latvia the responsibility of the Board is disproportionately high and the members of the board take more risks than in other countries with similar economies. Although the case law does not yet provide a much elaborate, legally formulated explanation of what it means to be a good and diligent entrepreneur in running a business, any board member will be able to find answers often, not only consulting with lawyers but listening to his or her own voice and conscience.

When analyzing the existing situation in practice it is also necessary to take into account the fact that on November 15, 2016 the Constitutional Court, recognizing the contested norms regarding the physical liability of the board member pointed out that, in carrying on a commercial activity in any form of commercial activity under the Commercial Law, a person must act in a manner consistent with the obligation to pay taxes in the public interest.

\section{Conclusions}

1. Corporate Social Responsibility is one of the most effective tools in fight corruption on the individual, corporate, national and international level. Corporations can play a leadership role in the anticorruption effort by treating corruption as a strategic Corporate Social Responsibility (CSR) issue and seeking proactive solutions to social problems critical to the business. More specifically, corporations can ensure compliance throughout all their divisions and countries; shift from diffuse declarations to outcome-oriented pacts that create effective incentives for behavior change; expand efforts to influence public sector corruption; leverage their financial, technical, and communication assets; and align and integrate resources and staff in order to execute swiftly on these approaches. The leading norms that deal with 'corruption' on the international level are the "UN Convention against Corruption (UNCAC)", the Convention on Combating Bribery of Foreign Public Officials (OECD Antibribery Convention).

2. The board of directors play four interlocking roles: they (1) set direction, (2) marshal the resources needed, (3) monitor and report on the resulting actions, and then (4) evaluate the result so as to enhance future performance by adjusting the direction. These roles serve two main purposes that need to find a balance but can frequently come into conflict: controlling the performance of managers and contributing to the creation of value. 
3. The answer to the first research question regarding the legal base is as follows: The Commercial Law of the Republic of Latvia (specifically section 169); "Convention on Combating Bribery of Foreign Public Officials in International Business Transactions" entitled "Good Practice Guidance on Internal Controls, Ethics, and Compliance"; the CSR platform, established and run by the Latvian Employers' Confederation; other laws of the Republic of Latvia, such as, the Law on Accounting, the Labor Law, the Tax Law.

4. Claims against the members of the board may be brought in two cases - if a member of the board violates the provisions of the law or if a member of the board acts in bad faith and contrary to the interests of the society (does not act as a good and prudent owner).

5. The answer to the second research question is: the top 3 risks of corruption and irregular practices considered the most impactful are: (i) receiving bribes; (ii) falsification and/or misrepresentation of company documents; (iii) false accounting and fraud.

6. Neither in the level of legislation nor in the case law there is reason to conclude that in Latvia the responsibility of the board is disproportionately high and the members of the board take more risks than in other countries with similar economies.

\section{Bibliography}

Arafa M. A.(2011). Battling Corruption within a Corporate Social Responsibility Strategy. Indiana International \& Comparative Law Review, 21(3), 397-418.

Carr I.,\&Outhwaite O.(2011). Controlling Corruption Through Corporate Social Responsibility and Corporate Governance: Theory and Practice. Journal of Corporate Law Studies, 11(2), 299-340.

CSR Platform in Latvia. (2011).Retrieved June 15, 2019 from http://en.lddk.lv/pakalpojums/a-corporate-social-responsibility-platform/

Legal Acts of The Republic of Latvia. (1992). The Civil LawRetrieved 20 August, 2019 from https://likumi.lv/ta/en/en/id/225418

Legal Acts of The Republic of Latvia.(1995). On Taxes and Duties. Retrieved 20 August, 2019 fromhttps://likumi.lv/ta/en/en/id/33946

Legal Acts of the Republic of Latvia. (2000a). The Commercial Law. Retrieved July 29, 2019 from https://likumi.lv/ta/en/en/id/5490

Legal Acts of The Republic of Latvia.(2000b). Insolvency Law. Retrieved August 13, 2019 fromhttps://likumi.lv/ta/en/en/id/214590

Nordberg D. Corporate Governance and the Board. (2011). Theory and Practice of Corporate Social Responsibility (pp. 39-54). Heidelberg, Dordrecht, London, New York: Springer.

OECD. (2011). Convention on Combating Bribery of Foreign Public Officials in International Business Transactions and Related Documents. Retrieved 
August 22, $2019 \quad$ fromhttps://www.oecd.org/daf/antibribery/ConvCombatBribery_ENG.pdf

OECD.(2018). State-Owned Enterprises and Corruption: What Are the Risks and What Can Be Done? Retrieved August 5, 2019 fromhttps://doi.org/10.1787/9789264303058-en

OECD Glossaries.(2008). Corruption. A Glossary of International Standards in Criminal Law. Retrieved August 5, 2019 fromhttp://www.oecd.org/daf/anti-bribery/41194428.pdf

Olsen W. P. (2010). The Anti-Corruption Handbook. How to Protect Your Business in the Global Marketplace. Hoboken, NJ : John Wiley \& Sons.

Republic of Latvia Supreme Court. Senate. Retrieved August 24, 2019 fromhttp://www.at.gov.lv/en

Rohwer A. (2009). Measuring Corruption: A Comparison Between the Transparency International's Corruption Perceptions Index and the World Bank's Worldwide Governance Indicators. Retrieved July 23, 2019 fromhttps://www.cesifo-group.de/portal/pls/portal/docs/1/1192926.PDF

Transparency International. (2016). Transparency in corporate reporting: assessing emerging market multinationals. Retrieved May 29, 2019 from https://www.transparency.org/whatwedo/publication/transparency_in_cor porate_reporting_assessing_emerging_market_multinat

Transparency International. (2018). Corruption Perception Index. Retrieves May 29, 2019 fromhttps://www.transparency.org/cpi2018

United Nations Global Compact. Retrieved August 23, 2019 fromhttps://www.unglobalcompact.org/what-is-gc/mission/principles

United Nations. (2004). United Nations Convention Against Corruption. Retrieved August 23, 2019 fromhttps://www.unodc.org/documents/brussels/UN_Convention_Against _Corruption.pdf

Vevere, V. \&Svirina, A. (2020). Business Ethics and Corporate Social Responsibility. Riga: EKA University of Applied Sciences.

Vevere V., Zvirgzdina R., \&LininaI.(2017). Indexes as Business Environment Characterizing Instruments. European Integration Studies, 11, 220-232.

YinR. K. (2018).Case Study Research and Applications: Design and Methods. $6^{\text {th }}$ Edition. Los Angeles, London, New Dehli, Singapore, Washington DC: Sage.

Zakenfelde, D. (2015).Valdes locekḷuatbildība par nodokḷuparādiem[Liability of board members for tax debts]. Retrieved August 15, 2019 fromhttps://lvportals.lv/skaidrojumi/268079-valdes-loceklu-atbildiba-parnodoklu-paradiem-ii-2015 